\title{
Actual Problems of Human Trafficking and Illegal Migration in the Russian Federation
}

\author{
Sergey V. Ryazantsev
}

Institute of Socio-Political Research of the Russian Academy of Sciences, Moscow, Russia

Irina S. Karabulatova

Institute of Socio-Political Research of the Russian Academy of Sciences, Moscow, Russia

Roman V. Mashin

Institute of Socio-Political Research of the Russian Academy of Sciences, Moscow, Russia

Elena E. Pismennaya

Finance Academy under the Government of the Russian Federation, Moscow, Russia

Svetlana Yu. Sivoplyasova

Institute of Socio-Political Research of the Russian Academy of Sciences, Moscow, Russia

Email: radogost2000@mail.ru

\section{Doi:10.5901/mjss.2015.v6n3s1p621}

\begin{abstract}
Human trafficking in the Russian Federation is closely linked to irregular migration into which huge numbers of people from the former USSR have been drawn. The European Parliament's fight against organized crime and money found 880 thousand. Modern slaves in the EU, writes the German weekly "Der Spiegel", become familiar with its report. In this business was involved about 3,600 international criminal gangs. Only trafficking in human beings brings $€ 25$ billion a year. Comparable income - € 18-26 billion - brings together trade bodies with a prohibited wildlife trade; the report said (Enslaved Europe, http://www.crime.vl.ru/index.php?p=4835\&more=1\&c=1\&tb=1\&pb=1\#more4835, 2015)). The author analyzes the problem of illegal migration, which became relevant in the present time in Russia. The data for the research was collected by employing statistical, sociological, cartographic and analytical methods. The report analyses the scale of trafficking for labour exploitation in the Russian Federation and its link to irregular migration. The system for the regulation of labour migration in the Russian Federation can be viewed as imperfect and currently incomplete, enabling the possibility for labour migrants to be actively drawn into human trafficking and labour exploitation by unscrupulous employers and criminals.
\end{abstract}

Keywords: trafficking in human beings, illegal migration, labor exploitation, the post-Soviet space, Russia.

\section{Introduction}

This research identifies the methods of recruiting migrant workers for the purpose of trafficking for labour exploitation. The mechanisms and methods used to recruit foreigners and Russian citizens into human trafficking are quite varied and are constantly being perfected by criminal structures. In recent years, a growing number of experts of the European countries on the basis of their analytical activity in recent years, transnational organized crime groups (OPG) come to the conclusion that the activities of organized crime groups has become a major threat to the XXI century. This threat is considered to be much more than a terrorist, which does not have the necessary forces and means to endanger the functioning of the state. According to experts the most widespread methods of recruitment in the Russian Federation are recruitment by different network structures, private individuals, independent recruitment, by firms and recruitment agencies and by state structures. The role of the internet in recruiting trafficking victims has grown considerably in Russia and the internet has become a major platform for recruiting victims of trafficking.

Human trafficking for labour exploitation has become a widespread phenomenon in many countries around the world. UN figures show that approximately 27 million people worldwide, including some 600,000 or so citizens of 
countries which were once part of the USSR, live in slavery (Nesteruk, 2005). Ultimately, the country's geographical position and transport links aided its transformation into a transit corridor between Asia and Europe through which trafficking victims are channelled. It should also be noted that there is a close link between human trafficking for labour and sexual exploitation and the phenomenon of irregular labour migration, into which huge numbers of people from the former USSR have been drawn (Ryazantsev et al, 2014; and Ryazantsev, S.V., R.V. Manshin and Khanh Toan Nguyen, 2013). To date, the query "trafficking in human beings in modern filmography" has over 300 thousand responses to the global Internet. And it is not only documentary, but movies about the problem of sexual slavery and forced labor. At the same time a request for trafficking in Russia has 34 million hits. All this testifies to the dissemination of this phenomenon in Russia and neighboring countries.

\section{Materials and Methods}

The research is based on statistical and sociological methods. The interview guide included questions designed to identify aspects of recruitment and involvement in human trafficking and irregular migration and focused on the following themes:

1) the interviewees' role/activity regarding labour immigration and migrant exploitation;

2) Practices of migrant labour exploitation and human trafficking (types, methods used, victims and perpetrators' profile);

3) Migrants' recruitment process;

4) Mechanisms to prevent migrant labour exploitation (role of employers, governmental institutions, policymakers).

In addition, 35 interviews with human trafficking victims or their representatives (parents/relatives) were conducted personally by the author or obtained from the database of the Moscow office of the International Organization for Migration between January - June 2013. For this, the author expresses sincere thanks to the staff at the IOM's office in Moscow. The interviews conducted for the study were anonymous. The names of the interviewees have been changed, because human trafficking poses significant risks to the safety of victims, particularly before investigations are complete. For this reason, it was not possible in principle to use some interviews in this report, so as not to endanger the lives of some individuals.

Academic organizations and research centres at universities have made a significant contribution to the formation of a conceptual apparatus and description of the issue of human trafficking and slave labour. Several major papers have been published in Russia covering issues of irregular migration, human trafficking and the exploitation of labour migrants. This research has been carried out by, among others, the Institute of Social and Economic Studies of Population at the Russian Academy of Sciences (RAS), the Institute of Socio-Political Research RAS, the Institute of Economic Forecasting RAS and Lomonosov Moscow State University.

The authors hopes that this article will go some way as a contribution to deepen understanding of the reasons, trends and issues surrounding human trafficking, the use of slave labour and the organization of irregular migration and trafficking, and ultimately that it will aid the possibility to suppress and reduce the scale of these adverse phenomena in the Russian Federation.

\section{Results}

The Russian Federation has also become host to a significant number of labour migrants from Central Asian countries and CIS states, China and Vietnam, who often fall prey to human traffickers. The territory of the Russian Federation is also used as a transit area by criminal groups who organize human trafficking.

The development of a Russian legal framework aimed at tackling human trafficking began later. 1996 saw the adoption of the Criminal Code of the Russian Federation, which contained an article that prescribed a penalty for the trafficking of children (article 152). Federal Law no. 162 "On amendments to the Criminal Code of the Russian Federation" was passed in December 2003. This law added two articles to the Criminal Code which criminalized human trafficking (article 127-1) and the use of slave labour (article 127-2) in the Russian Federation. This step constituted formal recognition by the government of the problem of human trafficking in Russia. The legal premises for the adoption of the aforementioned articles of the Criminal Code of the Russian Federation were the UN Convention "Against Transnational Organized Crime" and its supplementing Protocols: "Against the Smuggling of Migrants by Land, Sea and Air" and "To Prevent, Suppress and Punish Trafficking in Persons, especially Women and Children" (Levchenko, 2009).

Organized criminal groups involved in human trafficking now operate on an international level, include citizens of a 
wide range of countries, are well equipped and informed, are assisted by a broad support base of contacts, and have significant financial resources at their disposal. Naturally, the activities of such groups can only be suppressed through international cooperation and coordination of the activities of the law enforcement agencies in different countries. As has been pointed out in research, a large proportion of the ringleaders of criminal human trafficking groups in Russia have previous convictions, the criminal activity is also undertaken by women who have previously been involved/operated in prostitution. There have been cases where leaders of organized criminal groups, certain charitable organizations and overseas employment companies have been involved in activity connected with human trafficking (Zagorsky et al, 2009).

Human trafficking for sexual exploitation and labour exploitation is a complex phenomenon which, according to its legal characteristics, can be characterized by different parameters and can be classified by the Criminal Code of the Russian Federation under such articles as "Use of slave labour" (art. 127-2), "Incitement to prostitution" (art. 241), "Organization of prostitution" (art. 241), "Illegal distribution of pornographic materials" (art. 242), "Production and circulation of materials or items with pornographic images of minors" (art. 242-1) and "Organization of irregular migration" (art. 322-1).

Figure 1 - Breakdown of offenders prosecuted in the field of human trafficking and organization of irregular migration in $2012, \%$

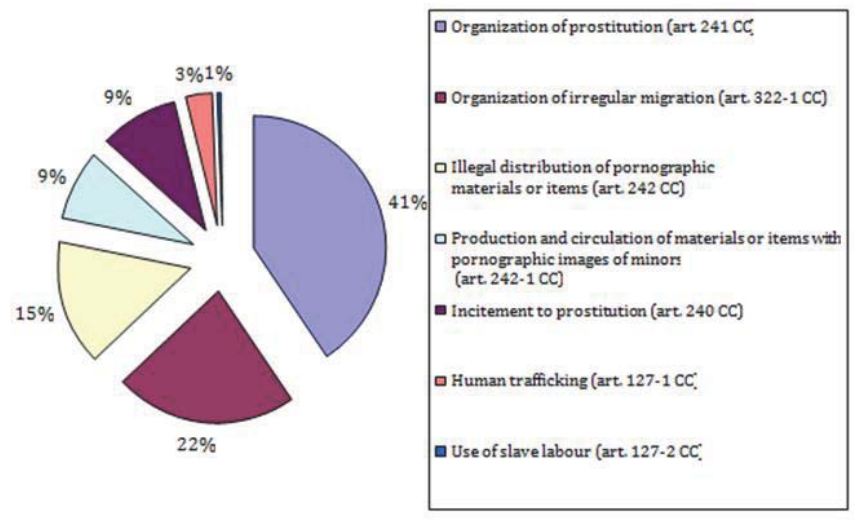

Source: Ministry of Interior of the Russian Federation.

Human trafficking is closely linked with labour exploitation. Article 127-1 of the Criminal Code of the Russian Federation lists the following types of exploitation: exploitation of the prostitution of others; other forms of sexual exploitation; slave labour (or services); servitude. Human trafficking can also be done for the purpose of removing organs and tissue from a person. In its conventional sense, exploitation of a person is defined as activity relating to the appropriation of the outcomes of another person's labour and deriving benefits and assets (Ozhegov and Shvedova, 1992). In the context of article 127-1 of the Criminal Code of the Russian Federation, the concept of exploitation of a person may be defined as systematic appropriation of the outcomes of another person's labour which is committed through deception, abuse of trust, violence or the threat of violence, or exploiting the injured party's dependent position.

Figure 2 - Breakdown of offenders prosecuted in the field of human trafficking and organization of irregular migration in $2012, \%$

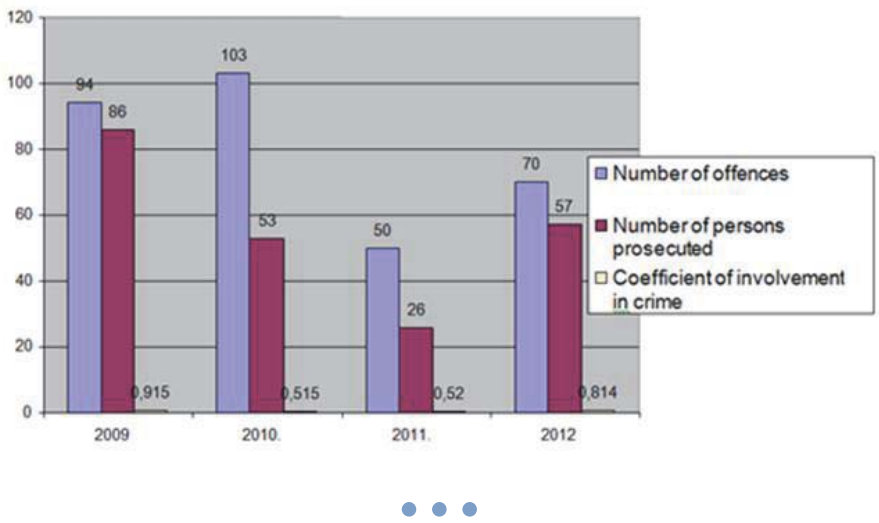


One form of exploitation of a person is slave labour, whereby the exploited person performs work while in a state of slavery or subject to customs or social institutions similar to it (Levchenko, 2009). Article 127-2 of the Criminal Code of the Russian Federation defines slave labour as forced labour of a person over whom powers inherent in the right of ownership are exercised, including if this person is unable, for reasons beyond his control, to refuse to perform the work (or provide the services). The turning point was brought about by the active work of experts and academics, ministries, international institutes and non-governmental organizations. In 2001, on the initiative of the Ministry of Foreign Affairs, the Commission on the Status of Women attached to the Government of the Russian Federation was launched. In 2002, an internal working group in the Ministry of Foreign Affairs was created to combat violence against women and human trafficking. In 2002, an inter-agency working group of the State Duma Committee for Civil, Criminal, Arbitration and Procedural Law was created to prepare a federal bill on counteracting human trafficking. In December 2003, Articles 127.1 "Human trafficking" and 127.2 "Use of slave labour" were entered into the country's Criminal Code, which allowed Russian law enforcement agencies to focus on and actively combat human trafficking. It should be noted that in 2004 the Russian Federation ratified the Protocol to Prevent, Suppress and Punish Trafficking in Persons, Especially Women and Children and the Protocol against the Smuggling of Migrants by Land, Sea and Air, supplementing the United Nations Convention against Transnational Organized Crime.

\section{Discussion}

The modern filmography reflects the problem of human trafficking as well. Feature film "Traffickers" (2012), produced by South Korea tells the story of smuggling in human organs. Yong-Kyu - the former leader of the gang engaged in trafficking in human organs. After the death of his friend, he decides to leave the group forever, and do not engage in human trafficking. Since then he has common mediator for smuggling goods into China. In one of the airports he meets a girl, cashier Yu-Ri and madly in love with her. However, she shows no desire to communicate with him, and she had so many worries. Her own father was terminally ill, and it can save only a heart transplant. Since the money for such an operation it does not, Yu-Ri refers to Don Bae, merchant bodies on the black market. Using the fact that Yong-Gu madly in love with this girl, Don Bae persuades him to return to his old gang. The whole gang is on the ship, where they have to cut out the heart of the kidnapped girl with a disability. Feature film "Human Trafficking" (2005) made in the USA and Canada tells the misadventures of Ukrainian women Nadia. This is a film about sexual slavery in a fall girls and young women from the former socialist camp. 16-year-old Ukrainian Nadia runs out of the house, tempted by work in a modeling agency in the West, and its traces are lost. Criminals kidnap in Southeast Asia 12-year-old American woman, Annie, who has come with his family on vacation. Young single mother Helena disappears in Prague, she was seduced by a wealthy businessman. The young 17-year-old Romanian Katherine disappears after a meeting with the alleged fiancé, whom she met on the Internet.

These girls share the fate of thousands of friends in misfortune. They become sex slaves in Europe, America and Asia. These are real stories. Detective Kate Morozov, and the immigration officer Bill Meehan trying to save the helpless victims and punish them heartless oppressors. The slogan of the film speaks eloquently about the problem: "Everyday, young girls are bought and sold". Researchers put the problem that the media can counteract slavery [Dzyaloshinsky and Tyuryukanova, 2008]. The authors point out the main trafficking routes. First of all, women and children, they come to the Middle East from Russia and neighboring countries (Ukraine, Belarus, Kazakhstan, Moldova). Immigrants from Moldova, Belarus, Ukraine and Russia are used in sexual slavery, while the natives of Kazakhstan, Uzbekistan, Tajikistan, Kyrgyzstan - in slave labor (Dzyaloshinsky and Tyuryukanova, 2008). According to Russian President Vladimir Putin, "trafficking in persons has become one of the most dangerous threats to civilization - along with organized crime, terrorism, drug addiction, drug trafficking" (Putin, V.V., http://ria.ru/politics/20040127/515035.html, 2014). The process of rehabilitation of former prostitutes is extremely difficult, "We know many cases where women spoke under threat of death or violence that they supposedly have made the decision to become prostitutes, although in reality the pimps / criminals are kept by force and used threatening their children or their families at home " - shows Petya Nesterov, head of the Council of Europe in charge of the fight against human trafficking (Prostitutes from the former Soviet Union master Pakistan, http://www.bbc.co.uk/russian/society/2012/01/120103_ex-soviet_prostitutes_pakistan.shtml, 2015). Russia joined the group of countries with the most acute problem of human trafficking, according to a US State Department report, devoted to slavery in the world. According to the classification of the report's authors, slavery thrives in Russia at the level of Saudi Arabia, Syria and Cuba (US acted against human trafficking in Russia, http:/lenta.ru/news/2014/06/ 21/slaveryl, 2014). The last decades of the newly exacerbated the situation related to contemporary forms of slavery, such as trafficking in women and children for later use them for sexual purposes. Criminal violence in these categories also includes beatings and beatings, rape, etc. The US State Department announced in 2012 that Russia, China and 
Uzbekistan are among the countries that have not only failed to meet the minimum requirements in the fight against trafficking in human beings, but are not making significant efforts to improve the situation. The Russian foreign ministry said the United States "is used inappropriate methodological approach, according to which the state is divided into rating groups depending on the political sympathies."The Chinese Foreign Ministry called on the US to "cease to act with baseless estimates" According to the existing order, the state $\mathrm{c}$ low rating may be subject to sanctions - refusal to finance educational and cultural exchanges, disagreement US states to receive assistance from the IMF and the World Bank (Russia and China have criticized the report of the United States of the Slave Trade, http://www.bbc.co.uk/russian/ international/2013/06/130620_russia_human_trafficking,2013).

\section{Conclusion}

Harder to the sale of women for the purpose of using it for surrogate motherhood. According to a survey of experts, $76.2 \%$ see such actions constitute a crime under Art. 127-1 of the Criminal Code, and 14.3\% of respondents did not believe such behavior trade. Come here, probably, from the fact, as the woman refers to the sale and a possible surrogate motherhood. With her consent to the one and the other, we should agree with the minority, because, again, there is no purpose of trafficking. Considering the complexity of understanding the purposes of trafficking, we asked the experts (experts) about one of them: "Is it true, in your view, an indication of the purpose of exploitation of man as a sign of criminal way trafficking?". Answers majority of survey participants were divided exactly evenly: by $42.9 \%$ found the need for such a sign, and have not seen it.

Even on a fully provocative, on our part, the question of qualification of actions that are recorded in the disposition of Art. 127-1 of the Criminal Code: "How, in your opinion, should evaluate the actions of recruitment, transportation, transfer, harboring or receipt of persons, committed for the purpose of its subsequent exploitation?", We have not received clear answers. Only $57.1 \%$ of respondents in a survey of experts believe that they should be evaluated as regulated in current criminal legislation of Russia - as independent alternative forms of socially dangerous acts constituting the objective aspect of trafficking in persons (art. 127-1 of the Criminal Code). According to 14.3\% of the respondents, qualification depends on the specific actions listed above - or as acquiescence aiding and abetting of actions to ensure the execution of transactions in respect of persons (art. 33, art. 127-1 of the Criminal Code), or as an attack on human trafficking (Art. 30, Art. 127-1 of the Criminal Code). A 4.8\% of all such actions are considered an attack on the use of slave labor (Art. 30, Art. 127-2 of the Criminal Code). Difficult question is to define trafficking in cases where symptoms are present in other similar crimes. So, we tried to find out from the experts (experts) whether under the current version of the criminal law to distinguish between standards regarding the responsibility for the recruitment of a person for the purpose of its use by others for the purpose of prostitution (Art. 127-1UK) and involvement in prostitution (art. 240 of the Criminal Code)? The vast majority of respondents - $71.4 \%$, and we think we should agree with them, answered this question in the negative. Similarly, the right, in our opinion, the experts (52.4\% in the survey of experts), arguing that additional qualifications of those responsible for the Art. Art. 126, 127 of the Criminal Code, if the direct transmission (in the framework of crimes under Art. Art. 127-1 and / or 127-2 of the Criminal Code) preceded his kidnapping or false imprisonment. Expert estimates and official statistics fundamentally do not match. Obviously, this is due to the highest latency analyzed criminal acts, which, last but not least, explains the inability of practice to identify and prove the crimes committed. Determining factor in the existence and development of human trafficking is a vast economic situation in Russia. Place among the various factors negatively affecting the trade in human beings, to deal in the legal regulation. It may be noted that the shortcomings in the economy play a more important role than the shortcomings in the legal regulation. Thus in conclusion it can be noted.

Since the introduction of the responsibility for trafficking in Russian internal affairs agencies investigated 13 criminal cases under Art. 127-1 of the Criminal Code of the Russian Federation. The turning point in the fight against trafficking in human beings has been the adoption of the Federal Law of 8 December 2003 № 162-FZ "On Amendments to the Criminal Code of the Russian Federation", which provided for criminal liability for trafficking in persons (Art. 1271), involvement in prostitution of minors (Art. 3 of Art. 240), the organization of prostitution (Art. 241).

Human trafficking is a modern form of slavery, reborn as a result of socio-economic problems in the society aimed to provide financial well-being of transnational organized crime. The initial stage of the international fight against this phenomenon is almost completed: a system of legal acts regulating the responsibility for human trafficking (national and international). But how viable will law enforcement. 


\section{Acknowledgement}

The article is prepared within the РФФИ grant, № 15-06-02854, "Economic-mathematical modeling of social reserves Russia's demographic development: a systems approach." And the RFBR grant № 15-36-20612 "Mathematical modeling of the demographic situation in Russia's regions with a high level of female emigration" mol_a_ved).

\section{References}

Dzyaloshinsky, I. M. and Tyuryukanova E.V., 2008. Trafficking in human beings: the media as a resource for the public to counter modern-day slavery. IOM in Russia. Moscow. 368 pp. [in Russian].

Enslaved Europe, Internet resource, 2013. http://www.crime.vl.rulindex.php?p=4835\&more=1\&c=1\&tb=1\&pb=1\#more4835 (Date accessed:24.02.2015).

Levchenko, O.P., 2009. Human Trafficking and Legalization of Criminal Profits. Issues of Prevention: A Scientific and Practical Guide. Edited by O.P. Levchenko. Moscow: Publisher: Unity-Dana. 221 pp.

Nesteruk, P., 2005. One day I read an ad in the newspaper.... In the: Emigrant. Issue 7. 17-32 pp.

Ozhegov, S.I. and N. Yu. Shvedova, 1992. Explanatory Dictionary of the Russian Language. Ed. by S.I. Ozhegov and N.Yu. Shvedova. Moscow. $212 \mathrm{pp}$.

Prostitutes from the former Soviet Union master Pakistan. URL: http://www.bbc.co.uk/russian/society/2012/01/120103_ex-soviet_ prostitutes_pakistan.shtml. (Date of access: 19. 02. 2015).

Putin V.V.: trafficking in human beings - a dangerous threat to civilization. URL: http://ria.ru/politics/20040127/515035.html. (Date of access: 01.23.2014).

Russia and China have criticized the report of the United States of the Slave Trade. Electronic resource. Online published: 2.06.2013. http://www.bbc.co.uk/russian/international/2013/06/130620_russia_human_trafficking (date of access 23.02.2015).

Riazantsev, S.V., Pismennaya E.E., Karabulatova I.S. and Charif Y.Akramov, 2014. Transformation of sexual and matrimonial behavior of Tajik labor migrants in Russia. In the: Asian Social Science. Vol 10, No.20, 2014, ISSN 1911-2017; E-ISSN 1911-2025. Published by Canadian Center of Science and Education. Online Published: September 24, 2014. doi:10.5539/ass.v10n20p1. http://www.ccsenet.org/journal/index.php/ass/article/view/40806/22527.

Ryazantsev, S.V., R.V. Manshin and Khanh Toan Nguyen, 2013. Comparative Analysis of Vietnamese and Chinese Migration to Russia. In the: Migration Law, Issue 1. 21-42 pp.

Tyuryukanova, E.V. 2006. Human Trafficking in the Russian Federation: Overview and Analysis of the Current Situation. Moscow: Institute for Urban Economics. 186 pp.

US acted against human trafficking in Russia. Electronic resource. date of publication: 22.06.2014. http://lenta.ru/news/2014/06/21/ slaveryl (date of access 24.02.2015).

Zagorsky, G.I., Kaufman M.A., Moiseeva T.F. and N.V., 2009. Radutnaya: Court Proceedings in Human Trafficking Criminal Cases. Moscow: Publisher "Yuridicheskaya literatura". 59 pp. 